\title{
The theater of Jan Klata. Struggling for a new audience
}

Aleksandra Konopko

a_konopko@o2.pl

\begin{abstract}
This short text presents the characteristics of theater works by the director, Jan Klata. I attempt to investigate the changes in contemporary Polish theatrical language. The evolution of theater perception, the expressive aesthetics of Klata's performances and topics that began the fight not only over the new theater that would be a place of socio-political discourses but also for the new audience.

In the introduction I present J. Klata and describe the circumstances that accompanied his theater debut. Thereafter, referring to J. Klata's staging of classical works, I point out the characteristics of his theater and describe how the phenomenon of reinterpretation functions in contemporary theater. I then try to question the explicit labeling of J. Klata's works as "post drama theater" or "political theater" by paying special attention to analyzing the director's works in a social context. This political and social background of J. Klata's performances contributes to the fact that his work is perceived as one of the leading examples of "engaged theater". The staging means of expression applied by the director and his often radical interference in the texts of works from the literary canon have encouraged younger directors to make their own daring experiments . What was perceived as "revolutionary" and controversial at the time of J. Klata's debut, today, only seven years later, has become standard in Polish theater.
\end{abstract}

Keywords: Jan Klata, Polish theater, engaged theater, political theater, social theater, new audience, reinterpretation of classical dramas, pop culture, Polish Catholicism, national myths and symbols

The theater of Jan Klata was introduced to Polish audiences only seven years ago. At that time national theatrical criticism was focused mainly on the artistic achievements of $\mathrm{A}$. Augustynowicz, P. Cieplak, Z. Brzoza and M. Fiedor. The very top positions were invariably occupied by the older masters - K. Lupa, J. Grzegorzewski, J. Jarocki - , who were the point 
of reference for the young generation of directors, inspiring them and provoking discussions. However, the "younger and more talented" $" 42$ directors increasingly began to achieve top positions.

It seemed that the main changes to the Polish theatrical scene had already taken place, as pointed out by T. Plata: "A lot has changed, almost everything. The primacy of the former masters (like J. Jarocki or A. Wajda) has been depleted by the generation of 30- and 40- yearold artists" (Plata 2006, p. 217). In this configuration of "theatrical powers" the name of J. Klata occurred unexpectedly. It was 2002. The director sent his drama Uśmiech grejpruta (Grapfruit's smile - the original title is misspelled on purpose) to the first edition of EuroDrama ${ }^{43}$ competition in Wroclaw. He provocatively signed his play with the nickname "Grzegorz Jarzyna" - perhaps because they studied together and G. Jarzyna started a great career right after graduation, while J. Klata could not get a job in his profession. When Uśmiech grejpruta $^{44}$ received an award, which gave the author a chance to direct his play as a workshop performance, only few people knew the playwright's? name. This anonymity changed after the success of Rewizor (Revisor), which was staged by J. Klata in Walbrzych in 2003. Since then, he has directed 20 plays and the media have kept talking about his activities and artistic image. He became a controversial and high-profile artist. Each of his productions provoked wide discussions and attracted broad audiences, which in fact was his target. J. Klata grew to be a leader in the struggle for a new theatrical language. The goal of this language was to reflect the condition of modern culture and help to attract new audiences.

J. Klata makes his performances spectacular and attractive, especially? for young people. Above all, he believes that theater can constructively influence the audience and start a dialogue. He claims that a theatre-maker has a mission and for that reason he never separates his plays from the social context. By observing reality and diagnosing it in the productions, he tries to create a new way of thinking by using various means of artistic creation. It is important to highlight that J. Klata builds his own means of expression, which

\footnotetext{
${ }^{42}$ The term "younger, more talented" was used by P. Gruszczyński to describe a group of 30- and 40-year-old directors characterized by their own style. In 1998 he published in "Dialog" an article titled Younger, more talented. The term was directly referring to an expression "young talented" used 30 years earlier by J. Koening with reference to artists: J. Grzegorzewski, H. Kajzar or R. Kordziński. P. Gruszczyński continues his reflections on Younger, more talented in his book Ojcobójcy. Młodsi zdolniejsi w teatrze polskim, Warsaw 2003.

${ }^{43}$ EuroDrama is a festival of modern drama that was started in December 2002 by P. Miśkiewicz, the thendirector of Polski Teatr in Wrocław. The organizers referred to the 35-year-old tradition of The Polish Contemporary Arts Festival' (that was taking place between 1963-1998 with several breaks), but they experimented with the form which made EuroDrama the first Polish festival to take the form of workshops. ${ }^{44}$ The opening night of Uśmiech grejpruta took place on the $5^{\text {th }}$ of December 2002, during the $1^{\text {st }}$ EuroDrama festival.
} 
he calls mental scratches and literary samples ${ }^{45}$. Scratches have often (but not always) a humoristic character and appear in those moments of the play when the director strongly tampers with the text or purposely suspends the action. They are a kind of reconstruction formed by pieces of art taken out of their contexts. Combined in a different configurations they create a new value. Similarly, sampling means composing pieces of texts and stage images without restraint to find out their alternative contexts.

The director and his artistic attitude became a popular topic for journalists and critics. Expressive means and an uncompromising attitude divided the audience into enthusiasts and opponents, but in both cases media perceived the artist as a "catchy" subject. Shortly after his debut J. Klata became not only one of the major directors of his generation, but also a "personality" of Polish culture. He owes this success to his intelligence, education, sensibility to social problems, and deep awareness of reality and modern culture. He also has a great ability to recognize, use and analyze its elements (e.g., mass media, music, comic strips, film, computer games, multimedia projections, clips, and animation).

J. Klata is not only a director, but also a playwright. He wrote his first play, Słoń zielony (Elephant green), which received an award in the Witkacy competition for children and teenagers, ${ }^{46}$ when he was only twelve years old. The text was published in the Dialog magazine in 1987; 11 years later fragments of the play were published in a handbook for eighth-grade students (series To lubie, Krakowskie Wydawnictwo Edukacyjne). His next plays, the already-mentioned Uśmiech grejpruta and Weź, przestań (Come on, stop it) (2005), ${ }^{47}$ were published in the newest anthologies of Polish modern drama: Pokolenie porno $i$ inne niesmaczne utwory teatralne (The Porn Generation and Other Tasteless Theatre Works) edited by H. Sułek, introduction by R. Pawłowski) and Echa, repliki, fantazmaty (Echoes, Replicas, Phantasms) edited by M. Sugiera and A. Wierzchowska-Woźniak). Additionally, J. Klata started a cooperation with Tygodnik Powszechny (General Weekly) as a columnist and actively participated in open discussions organized by Krytyka Polityczna. He is therefore continuously present in press and media, which indirectly promotes his theatre. At the same

\footnotetext{
${ }^{45}$ Both terms: 'sample' and 'scratch' come from the musical terminology. According to Stownik wyrazów obcych PWN, (Wisniakowska, L. (ed.), Warsaw 2004, p. 838 and 862) 'Sample' is a musical sound digitally stored and edited in a sampler; used to design music. 'To sample' means to compose music out of digitally stored sound samples. "Scratching" is a technique of moving a vinyl record back and forth on record player. Jan Klata translates these musical techniques into the language of the theater reshaping pieces of texts in a similar way as DJ does with the sounds.

46 The competition was organized in 1986 by Współczesny Theater in Wroclaw, Dialog magazine, The Ministry of Culture and Science and The Ministry of Education.

47 Jan Klata directed Weź, przestań by himself in Teatr Rozmaitości in Warsaw, the opening night took place on $21^{\text {st }}$ of April 2006.
} 
time, due to these actions, the director has been called a "revolutionist", a "provocateur", a "rebel", a "patriot in bovver boots" or a "catholic with Iroquois haircut" (J. Klata admits he carries a rosary in his pocket). There have been many articles about the director's image while the analyses of his plays were usually reduced to short post-premiere notes in newspapers and a few deeper critiques in professional theatrical magazines. This lack of serious critical attention shows that a strong image in the media can be dangerous, for it can focus the critics' interests on the artist himself more than on his art.

To date, the only broader study dedicated to J. Klata's theater is a special monographic edition of Notatnik Teatralny (Theatrical Notes) (38/2005), which aimed to summarize his works. However, Kronika (a part of the Notatnik Teatralny) by J. Minałto stops at the year 2006. Moreover, the authors focused only on few performances: primarily Rewizor (The Inspector General) and ...córka Fizdejki (... Fizdejka 's daughter), and also on H. (H.), Fanta\$y (Fanta\$y), Nakręcana pomarańcza (A clockwork orange), and Lochy Watykanu (Vatican's dungeon). The edition also includes several articles on the director's achievements and attitude, among which two texts seem to be the most interesting: Niepoprawny. Kontrowersje wokót wymowy ideowej przedstawień Klaty (Incurable. Ideological controversy around the J. Klata's theater) by R. Węgrzyniak and Reżyser idzie na wojnę (The director goes to war) by P. Gruszczyński. In addition, it (Notatnik Teatralny) includes interviews with J. Klata, J. Łagowska, M. Kaczmarek, K. Lupa and actors from theatres in Walbrzych and Gdansk. Apart from this special edition of Notatnik Teatralny, there also exists a short paragraph dedicated to J. Klata in Tsunami młodości (The tsunami of youth) by Ł. Drewniak published in a collection of texts titled Strategie publiczne, strategie prywatne. Teatr polski 1990 -2005 edited by T. Plata. Nevertheless, no one attempted to analyze fully the works of J. Klata ${ }^{48}$. In this study I will point out the characteristics of J. Klata's theater and identify the different means of expression employed by the director to build the specific language of his artistic communication, because this language becomes also his tool in a struggle for the new theatre.

The most significant among J. Klata's stage productions are reinterpretations of classical dramas that form a compendium of his theatrical knowledge. This study does not aim to evaluate the phenomenon of reinterpretation of classical dramas, but rather to indicate its contemporary shape. I will present how the director attempts to decrease the historical distance between the play and the audience. And although the style of J. Klata's performances

\footnotetext{
${ }^{48}$ I am the first who made this analysis. I did it in my Master thesis: The theater of Jan Klata. Struggling for a new audience, 2008.
} 
is very individual, I argue that by accustoming the audience to very bold interference into classical texts and experimenting with them in a drastic and extreme way, his productions broke new ground for other artists. Every new spectacle of J. Klata confirms the continuous evolution of his theater. It is now apparent that his artistic style is not a temporary trend, but one of the most important phenomena of Polish theatre. At the same time J. Klata's works are one of the most significant examples of addressing social problems in Polish theatre.

The performances of classical dramas are the most controversial among J. Klata's works. They receive enthusiastic reviews, but at the same time raise doubts because the director consistently? surprises the audience with non-standard interpretations of literary canon. J. Klata always transfers classical works into contemporary language, quite often placing the action directly in Polish social and political context. When everyday reality is reflected on the stage, it is difficult to expect the audience members to keep their distance from the plot and the problems of the play. In this way the audience is situated in the middle of the presented world. The theater no longer exists to entertain, but to create space for a dialogue and for uncomfortable, sometimes painful questions. Depriving the audience of the safe position of the distanced observer seems to be, for J. Klata, the director's main goal. He wants an audience that expects not only entertainment and political correctness, but also discussion, shock and honest diagnosis. it is obvious that the author of Usmiech grejpruta is neither the first nor the only director who, in his plays refers to the contemporary world through treating classical dramas as backgrounds for completely new stories. This theater model has dominated since the Great Theater Reform in the $19^{\text {th }}$ century, when the director and his vision (not the author's suggestions) became fundamental for the performances.

In the second half of the $20^{\text {th }}$ century the deconstruction of texts and re-writing originals were characteristic for J. Grotowski, J. Szajna and J. Grzegorzewski. Although the ways of staging performances and artistic methods of J. Klata undeniably differ from the theatrical language of J. Grotowski, it is possible to notice a few analogies in the way both artists interfere with texts and in their passion for political allusions.

What distinguishes J. Klata from other contemporary artists is the sharp theatrical language and radicalism of his artistic visions. For example, while referring to pop culture, he does not use it in the performance as a quote, but instead completely "plunges" his story into it. One can say that the director lives in a symbiotic relationship with the mass culture. He uses it consciously, emphasizing that the mass culture is the Polish contemporary reality. Simultaneously, using pop culture in new contexts he attracts a broader, mainly young, new 
audience. Thus the classical literature is for J. Klata an extremely important point of reference. This is confirmed not only by the numerous productions based on classical works, but also by the choices he makes. He always chooses the most important and challenging dramas. If he works with a text by William Shakespeare, he chooses the most famous of his plays - Hamlet. If ancient tragedy, then Aeschylus's trilogy, and if J. Słowacki, then Fantazy - a play that breaks the pattern of romantic works. Social criticism is more forceful when one creates one's own opinions based upon subjects that have been repeatedly discussed in crucial historic moments. This is the power of the classics; therefore J. Klata willingly builds his message against its background.

It is possible to notice an interesting regularity. If we study carefully his stagings of classical dramas, we can observe that they form a kind of historical chronicle. Klata starts with a critical review of Communist Poland (Rewizor) to demonstrate how that period influenced the Polish national mindset and how deeply it is still rooted in our reality. Then in Hamlet (H.), he evokes a reminiscence of Solidarity (Solidarność) and the events in Gdańsk in 1970, while at the same time posing the question of what remains of those ideas. In ...córka Fizdejki J. Klata mentions another important moment, the accession of Poland to the European Union, and considers whether EU membership can change the difficult situation of such places as Walbrzych. The play Fanta $\$ y$ reflects on the social situation in Poland during and after European Union accession. Here J. Klata presents the degradation and fall of Polish Intelligentsia and the reasons why our soldiers have decided to join the American war with Iraq. There is also an interesting analogy between Fanta\$y and Rewizor. In Rewizor he shows that during the governance of Gierek ${ }^{49}$ a two-bedroom apartment in a block of flats was a top luxury indicating a high social position (the Horodniczy family (Ojciec miasta) lived there). In Fanta\$y the fact that a well-educated and respected family lives in an old block of flats symbolizes degeneration. Oresteja (The Orestei) presents a vision of the world after a catastrophe. The scenography illustrates various calamities that took place recently; most prominently featured are the attacks on the World Trade Center in New York on September 11, 2001 The staging of ancient tragedies also points out other changes - this time rather global than local - pop culture and media rule the world and directly influence human lives.

In his next reinterpretation J. Klata again looks directly at Poland. In Szewcy u bram (Shoemakers at the gates) he shows a reality that is devoid of high culture. He refers to

\footnotetext{
${ }^{49}$ Edward Gierek - a Polish communist politician; First Secretary of the Polish United Worker's Party 19701980 .
} 
contemporary politics (e.g., Z. Ziobro, The Internal Security Agency, commissions of inquiry) to indirectly evaluate the administration of Law and Justice Party (PIS) in the $4^{\text {th }}$ Republic of Poland. Sprawa Dantona (Danton's Case) diagnoses the historical chronicle pessimistically. The real changes in social mechanisms have no chance to happen in the contemporary world. Revolution remains utopia. And the image presented by J. Klata is clearly an anti-utopia, a vision of cataclysm - the only possible result of social change.

Another sequence of historical references presents images of Edward Gierek, Adolf Hitler, John Paul II and even currently popular politicians as Z. Ziobro. Therefore the plays of J. Klata can be partly perceived as the director's personal re-interpretation of culture and history. This tendency in J. Klata's theater resembles some of Brecht's practices, which also emphasize the historical aspect in his plays. To be more precise I would like to quote P. Pavis: "Brechtian often refers to "politics of sign« - space and text provide a space for theater practice and signify reality through a system of signs that are at once aesthetic (rooted in stage materials or in a given stage craft) and political (criticizing reality rather than imitating it passively)" (Pavis 1998a, p.39). And further: "In Brechtian dramaturgy, as in a staging inspired by critical Bretchian realism, to historicize is to refuse to show human beings in an individual, anecdotic light; to reveal the underlying sociohistorical infrastructure beneath the individual conflicts. In this sense, the individual drama of the hero is recontextualized socially and politically and any theater is historical and political" (Pavis 1998b, p.171).

The above descriptions are also relevant to J. Klata's performances. However, a polemical debate exists as to whether J. Klata's art should be unambiguously defined as "political theatre" or "post-dramatic theatre" (a term appearing occasionally in articles about J. Klata). It seems that J. Klata's works do not fit any unequivocal definitions, since his spectacles summarize various characteristics of particular theater methods. Describing the director's style as "social theatre" rather than "political theatre" seems the most pertinent, but of course these terms are not mutually exclusive.

P. Mościcki proposes a division of political theater into engaged theatre, which reflects and comments on the arena of politics, and engaging theatre, which, through observing reality and referring to it in a play, aims to influence the environment and to create a new way of thinking. J. Klata should be mainly associated with the engaging theatre. Whereas the associations with the post-dramatic theater can provide enough material for a separate study, it is worth remarking that some characteristics of J. Klata's artistic language 
can be aligned to the post-dramatic theater, while other are completely unlike or only partly convergent.

A separate concern is the term "post-dramatic theatre" itself, as it has not yet been fully and clearly described. The basic compendium of this subject is a monograph by H-T. Lehmann, but as the author himself emphasizes it is only "an attempt to create an aesthetic logic of the new theatre" (Lehmann 2004a, p. 11), and many topics could only be mentioned. Therefore it seems inadequate to define Klata's plays as post-dramatic theatre. Nevertheless, following H-T. Lehmann's analysis one can identify several characteristics of J. Klata's works that align surprisingly well with the above-mentioned theory.

It is worth noticing that the features of post-drama reflected in J. Klata's theater that I would like to mention here are not assigned only to this particular trend, but many of them have already appeared in former theatrical practices, starting from the changes initiated by the Great Theater Reform. According to H-T. Lehmann the post-dramatic theater is defined by a key transformation of methods using theatrical signs (e.g. visual, spatial or gestural). At the same time we can notice a new, different attitude towards drama itself. The text is no longer dominant, but instead is treated as an element or a layer of stage composition, which is typical for J. Klata's works. Nonetheless, the term "post-drama" still refers to drama as a literary genre and indicates its connections with the theatre. In J. Klata's performances this relation can be easily noticed in the text's deconstruction of original literary works or in the already-mentioned mental scratches and samples added by the director.

Post-drama performances are often staged in "non-theatrical" settings, such as factories, halls or power stations. When this kind of location serves as a stage, such as the Gdansk Shipyard did in $H$., the setting gains a new aesthetic value and simultaneously becomes a co-author of the spectacle. Another visibly characteristic element of J. Klata's works is a way of stage editing that is similar to cinema aesthetics and elicits "a specific sort of perception, that resembles the eye's? reaction to film cuts" (Lehmann 2004b, p. 205). (e.g. ...córka Fizdejki, Szewcy u bram, Sprawa Dantona, but also Nakręcana pomarańcza, and Lochy Watykanu). These are only a few of the recognizable analogies between J. Klata's theater and post-dramatic practices. Finally, one can conclude that the director teeters on the edge of dramatic and post-dramatic theater and by experimenting with both forms, creates his individual style.

All the above-mentioned practices, like playing with texts and searching for common ground for various forms and theatrical means, recall an association with palimpsest. The 
multi-narrative character of both the plot and the stage image overlap, thus creating a new story.

Undoubtedly J. Klata creates the author's theatre, achieving this inter alia by means of the characteristic stage language he uses to build his performances. In sum, it is valuable to point out his most recognizable elements:

- the role of music. Songs come from both pop- and counter-culture, but also from classical music. Other than building a specific mood, the songs also function as interpretational hints. Not only the lyrics, but also the socio-political context of the song are important;

- symbiosis with pop culture. Te director consciously refers to mass culture, thereby showing that it is the "natural environment" of the contemporary world.

- numerous references to the aesthetics of comics, film, animation, computer games, but also to old paintings;

- text as a starting point to the story of the contemporary world;

- references to historical events and figures, and also to currently popular politicians;

- rapid changes and thoughtful considerations of the spectacle's tempo - that is often similar to film editing technique.

- the importance of choreography and stage movement (permanent cooperation with M. Prusak);

- recurrent motives: Polish Catholicism, denouncing national myths and symbols, a criticism of the society, anti-utopia;

- the local context. The subject of the play connects to the city where the performance takes place;

- cooperation with amateur actors (boyars in ...córka Fizdejki, in a casting scene in $H$., history witnesses in Transfer!);

- the specific staging and feeling of theatrical form;

- accumulation of numerous motives and means in one performance.

Seven years of J. Klata's creative work has proved that his position is still strengthening. He has gathered not only a group of permanent coworkers (stage designers J. Lagowska and M. Kaczmarek, choreographer M. Prusak, dramaturg/assistnant A. Włodarska) and frequent collaborators (dramatists - S. Majewski and S. Sierakowski), but also a team of loyal actors as W. Cichy, M. Czarnik and E. Lubos. 
Since 2003 the theater of J. Klata has been changing, developing and defining its character. Today one can claim that this director's specific language, which is "revolutionary" for the Polish theatre, has become a standard tool. What is next then? What direction will Jan J. Klata choose? It is hard to tell yet. The struggle goes on ${ }^{50}$.

\section{Bibliography:}

Adamiecka-Sitek A. (2005), Teatr i tekst. Inscenizacja $w$ teatrze postmodernistycznym, Księgarnia Akademicka, Kraków.

Antoniewicz G. (2005), Słowacki nie tylko dla brunetów, ’Dziennik Bałtycki”, 239.

Balme Ch. (2002), Wprowadzenie do nauki o teatrze, Wydawnictwo Naukowe PWN, Warszawa.

Baran M. (2005), Desperacja Respekta, ”Gazeta Wyborcza-Trójmiasto”, 227.

Barthes R. (1997), Przyjemność tekstu, Wydawnictwo KR, Warszawa.

Barthes R. (1996), Światto obrazu. Uwagi o fotografii, Wydawnictwo Aletheia, Warszawa.

Baudrillard J. (2005), Symulakry i symulacja, Wydawnictwo Sic!, Warszawa.

Biernacka J. (2005), Nie jestem zasłużonym działaczem kultury. Rozmowa z Wiesławem Cichym, "Didaskalia", 65-66.

Błoński J. (2002), Między literaturą a światem, Wydawnictwo Literackie, Kraków.

Brand M. (2004), Hamlet gra w turbogolfa, "City Magazyn Trójmiasto", 7.

Braun K. (1984), Wielka reforma teatru w Europie, Wydawnictwo Ossolineum, Wrocław.

Brown J. R. (ed.) (2002), Historia teatru, Wydawnictwo Naukowe PWN, Warszawa.

Bukowska-Schielmann M. (2004), Tymczasowa rzeczywistość, Wydawnictwo Uniwersytetu Gdańskiego, Gdańsk.

Burzyńska A. (2001), Dekonstrukcja i interpretacja, Wydawnictwo Universitas, Kraków.

Chmielowski P. (2002), Słowacki w supermarkecie: szkice o polskim dramacie, Wydawnictwo Czarny Kot, Gdańsk.

Cieślak J. (2005), Mezalians miłości z pieniędzmi, "Rzeczpospolita", 242.

Cieślak J. (2005), Patriota, rocznik 1973,"Rzeczpospolita - Plus Minus”, 129.

Cieślak J. (2006), Polityka jest jak okrutny western, „Rzeczpospolita”, 235.

\footnotetext{
${ }^{50}$ A reference to J. Klata's theatrical manifest announced in 2005: “A human being needs two things: food and an opponent. I do have food, I am glad it is war time".
} 
Cieślak J. (2007), U bram V RP konsumenckiej, „Rzeczpospolita”, 262.

Czapla A. (2006), Rozmowa z Janem Klata, "Gazeta Wyborcza-Katowice”, 56.

Czapska I. N. (2005), Bunt, szok i fantazje, "Życie Warszawy”, 279.

Czapska I. N. (2006), Paszporty i nagie miecze, "Życie Warszawy", 9.

Debord G. (1998), Społeczeństwo spektaklu, Państwowy Instytut Wydawniczy, Gdańsk.

Degler J. (ed.) (2003), Problemy teorii dramatu i teatru, Wydawnictwo Uniwersytetu Wrocławskiego, Wrocław.

Derkaczew J. (2008), Gadajace głowy u Klaty, "Gazeta Wyborcza", 78.

Derkaczew J. (2006), Sezon na kobiety, czyli co nas czeka na scenach, "Gazeta Wyborcza”, 9.

Drewniak Ł. (2005), Kosmonauci polskiego teatru, "Notatnik Teatralny”, 38.

Drewniak Ł.(2006), Polak, czyli Rumun i Niemiec, ”Dziennik”, 177.

Drewniak Ł. (2005), W oku salonu, ’Przekrój”, 8.

Drewniak Ł. (2005), Wziać świat na klatę, ’Przekrój”, 49.

Dziewulska M. (2006), Dziadkobójcy, ’Tygodnik Powszechny”, 25.

Fox D., Wachocka E. (ed.) (2006), Teatr - media - kultura, Wydawnictwo Uniwersytetu Śląskiego, Katowice.

Frankowska B. (2003), Encyklopedia teatru polskiego, Wydawnictwo Naukowe PWN, Warszawa.

Gadamer H.G. (2004), Prawda i metoda, Wydawnictwo Naukowe PWN, Warszawa.

Głowacka I. (2006), Wywiad Metropolu, "Metropol”, 76.

Gruszczyński P. (2006), Bilans 2005. Kultura, ”Tygodnik Powszechny", 1.

Gruszczyński P. (2006), Klata - nieprzyjemny widok na śmietnik, "Gazeta Wyborcza", 6.

Gruszczyński P. (2006), Nowi niezadowoleni, ”Tygodnik Powszechny”, 24.

Gruszczyński P. (2003), Ojcobójcy. Młodsi zdolniejsi w teatrze polskim, Wydawnictwo W.A.B., Warszawa.

Gruszczyński P. (2005), Reżyser idzie na wojnę, "Notatnik Teatralny", 38.

Gruszczyński P. (2004), Wawel na mnie nie działa, ”Didaskalia”, 63.

Gwóźdź A., Krzemień-Ojak S. (ed.) (1998), Intermedialność w kulturze końca XX w., Wydawnictwo Trans Humana, Białystok.

Herbut A., Ziomek Ł. (2006), Tylko to, co radykalne. Rozmowa z Janem Klata, "Didaskalia" 71.

Kardasińska D. (2004), Dorosnąć do widowni. Rozmowa z Janem Klata, "Notatnik Teatralny", 32-33. 
Klata J. (2004), O prawdzie i nieprawdzie, etyce i estetyce, "Notatnik Teatralny", 32-33.

Klett R. (2005), Jan Klata!, ”Notatnik Teatralny” 38.

Kłosowski J. (2002), Słownik teatru polskiego: artyści i ich dzieła, teatry, historie, główne zjawiska, terminy teatralne, Wydawnictwo Muza, Warszawa.

Konopko A. (2005), Teatr jest z natury cyrkiem. Rozmowa z Janem Klata, "Indeks", 3-4.

Kornaś T. (2006), Niebo gwieździste czy ptaki fruwajace, ’Didaskalia”, 71.

Kosiński D. (2004), Sceny z życia dramatu, Wydawnictwo Księgarnia Akademicka, Kraków.

Kościelniak M. (2006), Samotność w teatrze, ”Tygodnik Powszechny”, 31.

Kościelniak M. (2007), Tracanie kijem, przesuwanie znaczeń..., "Tygodnik Powszechny”, 45.

Kowalska J. (2005), Egzorcysta, ”Notatnik Teatralny”, 38.

Kowalska J. (2004), Wojna domowa, ”Notatnik Teatralny”, 32-33.

Kozłowska-Głębowicz E. (2006), Klatka dla felietonisty, ’Tygodnik Powszechny”, 7.

Krupiński W. (2006), Kulturałki: To ja, kołkofob, ”Dziennik Polski”, 30.

Kuc M. (2006), Plany Jana Klaty, ’Rzeczpospolita”, 19.

Kuźnik M. (2006), Radość z wojny, "Exklusiv", 37.

Lehmann H. T. (20040, Teatr postdramatyczny, Wydawnictwo Księgarnia Akademicka, Kraków.

Lichotka J. (2008), Kłótnie obciętych głów, ”Rzeczpospolita - Plus Minus”, 87.

Lichotka J. (2007), To nie koniec historii 'Rzeczpospolita", 275.

Ligarzewska N. (2005), Podrapać tę strukturę. Rozmowa z Mirosławem Kaczmarkiem, "Notatnik Teatralny”, 38.

Ligarzewska N. (2005), Relacje. Rozmowa z Joanna Bogacka, Marcinem Czarnikiem, Grzegorzem Gzylem i Marta Kalmus, ”Notatnik Teatralny”, 38.

Limon J. (2006), Fanta\$y Jana Klaty, czyli sztuka o sztuce, ”Teatr”, 7-8.

Limon J. (2002), Między niebem a scena. Przestrzeń $i$ czas $w$ teatrze, Wydawnictwo Słowo/Obraz/Terytoria, Gdańsk.

Lubos E. (2005), Always no, ”Notatnik Teatralny", 38.

Maciejewski Ł. (2005), Dziwny dynamit. Rozmowa z Krystianem Lupa, "Notatnik Teatralny”, 38.

Markowski M. (2005), Jestem zawsze kontra, "Metropol”, 220.

Mieszkowski K. (2005), W Polandzie. Rozmowa z Janem Klata, "Notatnik Teatralny”, 38.

Migdałowska K. (2005), Do Timbuktu, "Notatnik Teatralny”, 38.

Miłkowski T. (2006), Rzucili Klatę, "Przegląd", 2. 
Minałto J. (2005), Kronika, "Notatnik Teatralny”, 38.

Minałto J. (2005), Polaków portret ironiczny, ”Notatnik Teatralny”, 38.

Mościcki T. (2006), Zbieg ciekawych okoliczności, "Odra”, 3.

Nowak M. (2007), Drugie życie teatru, ”Wprost", 50.

Nyczek T. (2005), Teatr Klaty - rewolucja na niby, "Gazeta Wyborcza", 293.

Pavis P. (1998), Stownik terminów teatralnych, Wydawnictwo Ossolineum, Wrocław.

Pawłowski R. (2004), Co się wydarzyło w 2004 roku w teatrze, "Gazeta Wyborcza”, 300.

Pawłowski R. (2005), Głosujcie na Klatę, ”Notatnik Teatralny”, 38.

Plata T. (ed.) (2006). Strategie publiczne. Strategie prywatne. Teatr polski 1990-2005,

Wydawnictwo Świat literacki, Izabelin.

Polak C. (2008), Rewolucja u bram Polski, ’Dziennik", 53.

Poprzędzka M. (2008), Ludzkie tworzywo, ”Tygodnik Powszechny”, 28.

Rokicka M. (2005), Intensywne życie z szachista. Rozmowa z Justyna Łagowska, "Notatnik Teatralny", 38.

Rokicka M. (2006), Samplowanie klasyki, "Arte", 3.

Ruszpel M. (2007), Bądźcie czujni "Szewcy u bram”!, ”Zwierciadło", 11.

Sieradzki J. (2005), Jan Klata, czyli pasja, ”Notatnik Teatralny”, 38.

Sieradzki J. (2005), Po co Hamletowi komórka?, "Polityka", 7.

Sieradzki J. (2006), Popyt na niezadowolenie, ”Tygodnik Powszechny”, 26.

Sierakowski S. (2005), Uderz silniejszego!, "Notatnik Teatralny”, 38.

Sławoń R. (2007), Spór o teatr w Polsce, ’Teatr", 7-8.

Sobak P. (2006), Istnieje jeszcze takie słowo, jak bohaterstwo, ”Opcje”, 1.

Stiller R. (2005), Co robić z ta pomarańczq̨?, "Notatnik Teatralny”, 38.

Targoń J. (2004), , ,H. ” W.S. i J. K., ’Didaskalia”, 63.

Targoń J. (2006), Marsjańskie porosty, ”Gazeta Wyborcza - Kraków”, 12.

Turner V. (1988), Teatr codzienności, codzienność w teatrze, ’Dialog”, 9.

Tyszka J. (ed.) (1998), Teatr w miejscach nieteatralnych, Wydawnictwo Fundacji Humaniora, Poznań.

Ubersfeld A. (2002), Czytanie teatru, Wydawnictwo Naukowe PWN, Warszawa.

Wakar J. (2006), Od początku do końca świata, ”Ozon”, 14.

Węgrzyniak R. (2005), ...co nie chciała Niemca, ,Didaskalia”, 65-66.

Węgrzyniak R. (2004), Egzorcyzmowanie Lafcadia, ’Didaskalia", 63. 
Węgrzyniak R. (2005), Niepoprawny. Kontrowersje wokót wymowy ideowej przedstawień Klaty, "Notatnik Teatralny", 38.

Wirth A. (2002), Teatr jaki mógłby być, Wydawnictwo Księgarnia Akademicka, Kraków.

Wójtowicz A. (2004), Od Orfeusza do Studium po Hamlecie. Teatr 13 Rzędów w Opolu (1959-1964), Wydawnictwo Uniwersytetu Wrocławskiego, Wrocław.

Wójtowicz A. (2006), Teksty i preteksty, "Teatr", 7-8.

Wychodka E. (ed.) (1999), Od symbolizmu do post-teatru, Warszawa.

Zielińska M. (2005), Prowokator, "Ozon", 1. 